\title{
Ethnow
}

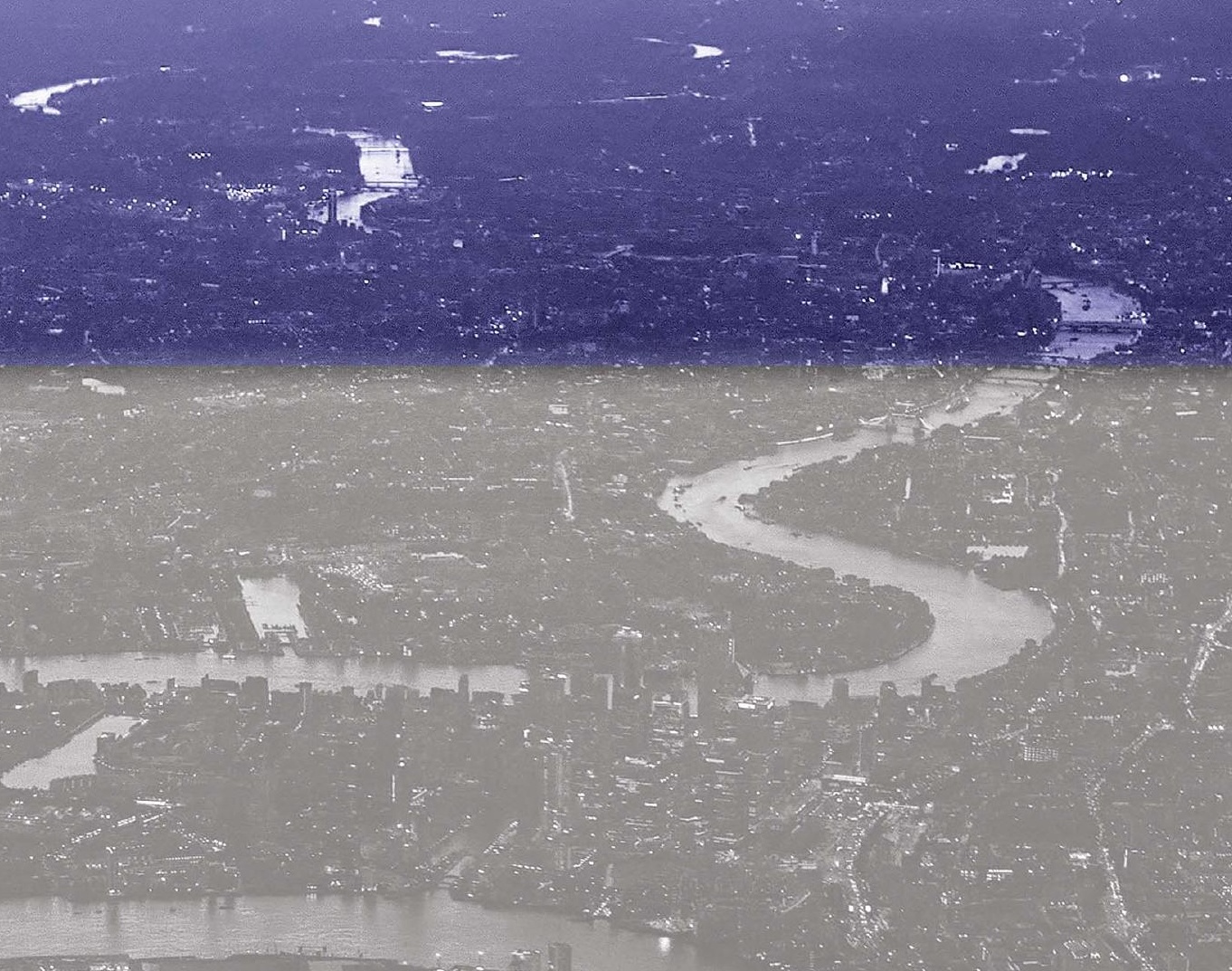

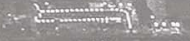
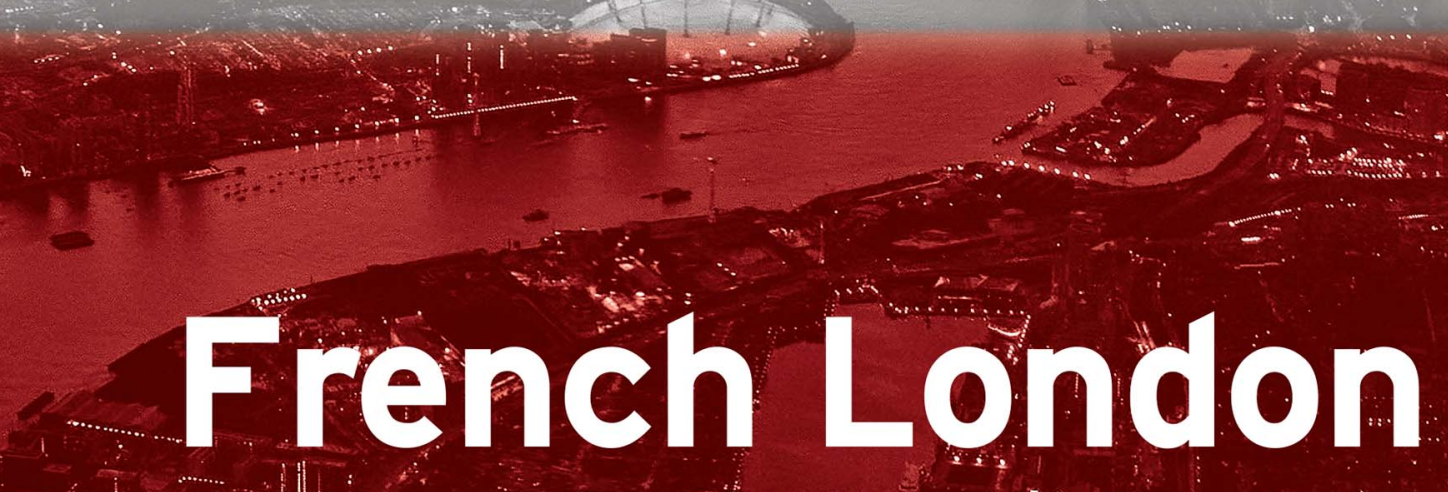

A blended ethnography of a migrant city

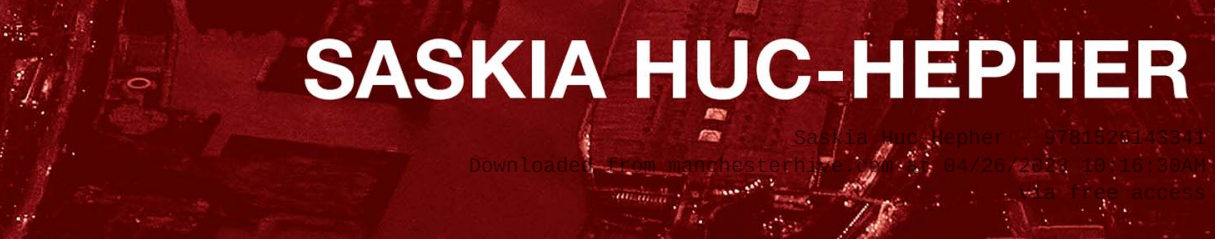




\section{French London}

\section{MANCHESTER 1824}

Manchester University Press 


\section{New Ethnographies}

Series editor

Alexander Thomas T. Smith

Already published

An ethnography of NGO practice in India: Utopias of development Stewart Allen

Disciplined agency: Neoliberal precarity, generational dispossession and call centre labour in Portugal Patrícia Alves de Matos

The British in rural France: Lifestyle migration and the ongoing quest for a better way of life Michaela Benson

Ageing selves and everyday life in the North of England: Years in the making Catherine Degnen

Salvage ethnography in the financial sector: The path to economic crisis in Scotland Jonathan Hearn

Occupational health and social estrangement in China Wing-Chung Ho

Chagos islanders in Mauritius and the UK: Forced displacement and onward migration Laura Jeffery

South Korean civil movement organisations: Hope, crisis and pragmatism in democratic transition Amy Levine

Integration in Ireland: The everyday lives of African migrants Fiona Murphy and Mark Maguire

Environment, labour and capitalism at sea: 'Working the ground' in Scotland Penny McCall Howard

An ethnography of English football fans: Cans, cops and carnivals Geoff Pearson

Iragi women in Denmark: Ritual performance and belonging in everyday life Marianne Holm Pedersen
Loud and proud: Passion and politics in the English Defence League Hilary Pilkington

Into the woods: An epistemography of climate change Meritxell Ramírez-i-Ollé

Literature and agency in English fiction reading: A study of the Henry Williamson Society Adam Reed

International seafarers and transnationalism in the twenty-first century Helen Sampson

Tragic encounters and ordinary ethics: The Palestine-Israel Conflict in British universities Ruth Sheldon

Devolution and the Scottish Conservatives:

Banal activism, electioneering and the politics of irrelevance Alexander Smith

Exoticisation undressed: Ethnographic nostalgia and authenticity in Emberá clothes Dimitrios Theodossopoulos

Immersion: Marathon swimming, embodiment and identity Karen Throsby

Enduring violence: Everyday life and conflict in eastern Sri Lanka Rebecca Walker

The religion of Orange politics:

Protestantism and fraternity in contemporary Scotland Joseph Webster

Performing Englishness: Identity and politics in a contemporary folk resurgence Trish Winter and Simon Keegan-Phipps 


\title{
French London
}

\section{A blended ethnography of a migrant city}

\author{
Saskia Huc-Hepher
}


The right of Saskia Huc-Hepher to be identified as the author of this work has been asserted by them in accordance with the Copyright, Designs and Patents Act 1988.

Published by Manchester University Press

Altrincham Street, Manchester M1 7JA

www.manchesteruniversitypress.co.uk

British Library Cataloguing-in-Publication Data

A catalogue record for this book is available from the British Library

ISBN 9781526143334 hardback

First published 2021

The publisher has no responsibility for the persistence or accuracy of URLs for any external or third-party internet websites referred to in this book, and does not guarantee that any content on such websites is, or will remain, accurate or appropriate.

Cover image: jplenio/pixabay

Cover design: riverdesignbooks.com

Typeset by

Servis Filmsetting Ltd, Stockport, Cheshire 